\title{
\begin{tabular}{l|l|l} 
Jurnal Eksplorasi Akuntansi & $\begin{array}{l}\text { ISSN : 2656-3649 (Online) } \\
\text { http://jea.ppj.unp.ac.id/index.php/jea/issue/view/21 No 1, Seri E, Februari 2020, Hal 2494-2512 }\end{array}$
\end{tabular}
}

\section{PENGARUH KONSERVATISME AKUNTANSI TERHADAP UNDERPRICING SAHAM IPO (INITIAL PUBLIC OFFERING)}

\author{
Meri Andani ${ }^{1}$, Salma Taqwa ${ }^{2}$ \\ ${ }^{1}$ Alumni Jurusan Akuntansi Fakultas Ekonomi Universitas Negeri Padang \\ ${ }^{2}$ Jurusan Akuntansi Fakultas Ekonomi Universitas Negeri Padang \\ *Korespondensi: meriandani309@gmail.com
}

\begin{abstract}
This study examines how the effect of accounting conservatism to IPO's underpricing and information asymmetry effect the association of accounting conservatism with IPO's underpricing. The sample of this study using the 97 a-shares companies that went public through IPO's at both Indonesia Stock Exchage during 2015-2018. Sampling was done by using total sampling method. The type of data used is secondary data obtained from annual report companys and stock price. Based on regression analysis with Eviews 9 we find (1) Accounting conservatism has no effect to IPO's underpricing. (2) Has no effect of high information asymmetry or low information asymmetry on association between accounting conservatism and IPO's underpricing.
\end{abstract}

Keywords: IPO's underpricing; Accounting conservatism; Information asymmetry.

How to cite (APA $6^{\text {th }}$ style):

Andani, M., \& Tawqa, S. (2020). Pengaruh Konservatisme Akuntansi terhadap Underpricing Saham IPO (Initial Public Offering). Jurnal Eksplorasi Akuntansi, 2(1). Seri E, 24942512.

\section{PENDAHULUAN}

Perusahaan yang baru go public ditandai dengan adanya penawaran saham perdana yang disebut juga dengan Initial Public Offering (IPO). IPO merupakan penjualan sekuritas oleh emiten yang dilakukan untuk pertama kalinya. Dari hasil penjualan sekuritas inilah perusahaan mendapatkan tambahan dana guna pembiayaan aktivitas keuangannya (Tandelilin, 2010). Ketika perusahaan melakukan IPO, masalah yang dihadapi adalah masalah penentuan harga di pasar perdana. Emiten akan mempersiapkan dokumen emisi untuk keperluan IPO berupa laporan keuangan. Dari laporan keuangan, manajemen perusahaan dapat mengetahui berapa harga saham wajar perusahaannya.

Akan tetapi harga saham wajar hasil perhitungan belum tentu dijadikan harga IPO karena harga IPO merupakan kesepakatan antara perusahaan (emiten) bersama pihak penjamin efek (underwriter), oleh sebab itu, sangatlah penting bagi underwriter menetapkan harga yang tepat (Ritter, 1987). Underwriter yang memiliki informasi lebih tentang pasar modal akan membuat kesepakatan harga IPO yang lebih rendah untuk memperkecil risiko apabila saham tidak terjual semua, sedangkan emiten yang kurang informasi mengenai pasar modal akan menerima harga 
yang murah bagi penawaran sahamnya dengan menerima dampak dana yang diperoleh tidak maksimum (Baron, 1982).

Harga saham pada penawaran perdana lebih rendah dibandingkan dengan harga saham pada saat hari pertama di pasar sekunder, maka akan terjadi fenomena yang disebut dengan underpricing (Hanafi, 2004). Kondisi underpricing menyebabkan terjadinya positif initial return dan anomali long term performance yaitu keadaan dimana dalam jangka panjang, kinerja saham IPO mempunyai kinerja yang jelek. Hal ini menunjukkan bahwa harga IPO yang disepakati bukanlah harga saham yang sesuai dengan nilai perusahaan atau harga wajarnya (Riyanto, 2013).

Underpricing ini merupakan fenomena yang terjadi di pasar modal diberbagai negara seperti Eropa, Amerika, China dan bahkan di pasar modal Indonesia itu sendiri. Berdasarkan data yang diperoleh dari situs resmi Bursa Efek Indonesia, underpricing telah terjadi pada 104 dari 121 perusahaan yang IPO sepanjang tahun 2015-2018. Maraknya fenomena underpricing yang telah terjadi menunjukkan bahwa harga saham pada saat penawaran perdana secara umum dapat dinilai murah (Jogiyanto, 2010).

Salah satu cara untuk mengurangi tingkat underpricing adalah menetapkan harga IPO yang sesuai dengan harga wajar perusahaan (Herawati et al, 2016). Harga wajar tercermin dari laporan keuangan yang diterbitkan oleh perusahaan sebelum melakukan IPO. Laporan keuangan yang disajikan tentu harus memiliki kriteria yang dapat menyakinkan penggunanya akan informasi tersebut. Salah satu karakteristik laporan keuangan yang baik menurut Ikatan Akuntan Indonesia (IAI) adalah reliability (keandalan). Informasi dikatakan andal apabila informasi tersebut tidak menyesatkan, penyajiannya dilakukan dengan jujur dan jauh dari tindakan manipulasi laporan keuangan. Salah satu yang dapat dilakukan untuk mencegah manipulasi laporan keuangan adalah dengan menerapkan prinsip konservatisme (Haniati dan Fitriany, 2010).

Konservatisme dalam akuntansi memerlukan standar yang lebih ketat dalam pembukuan gain or loss (Basu, 1997). Konservatisme akuntansi merupakan prinsip kehati-hatian manajemen dalam menghadapi ketidakpastian masa depan. Givoly (2000) mendifinisikan konservatisme sebagai prinsip yang segera pengakuan biaya dan rugi serta penundaan pengakuan pendapatan dan keuntungan, sehingga laporan keuangan yang dihasilkan dari pemakaian prinsip konservatisme adalah laporan keuangan yang understated (tidak berlebihan). Oleh karena itu dalam konservatisme akuntansi, laba dan aset yang dilaporkan akan lebih bisa diandalkan, dan konservatisme akuntansi akan membatasi manajemen perusahaan dari kesempatan melakukan overstating terhadap pendapatan dan understating terhadap beban (Bushman dan Piotroski, 2006). Dengan demikian informasi yang terdapat dalam laporan keuangan akan memuat mengenai nilai wajar perusahaan. Oleh karena itu, penerapan prinsip konservatisme akuntansi membantu dalam menetapkan harga IPO yang wajar dan selanjutnya akan menekan tingkat underpricing saham saat IPO.

Penerapan prinsip konservatisme akuntansi membantu mengurangi asimetri informasi antar pelaku IPO (emiten, underwriter, dan investor). Asimetri yang tinggi berdampak pada tingginya tingkat underpricing saham waktu IPO (Ljungqvist, 2007). Asimetri informasi merupakan kondisi dimana informasi yang dimiliki oleh pihak manajemen perusahaan tidak sama dengan informasi yang dimiliki oleh investor. Asimetri informasi dimulai oleh Akerlof (1970) yang menyatakan bahwa dalam pasar yang terjadi asimetri informasi, nilai rata-rata dan komoditi cenderung untuk turun, bahkan untuk barang yang tergolong kualitas bagus. Penjual yang tidak berniat baik akan menipu pembeli dengan cara memberi kesan seakan-akan barang yang dijualnya bagus, hal ini yang memunculkan adanya adverse selection. Sehingga pembeli akan menghindari penipu dan menolak untuk melakukan transaksi dalam pasar tersebut. Sebagai 
akibatnya, penjual yang benar-benar menjual barang bagus menjadi tidak laku karena hanya dinilai murah oleh pembeli, dan akhirnya pasar akan dipenuhi oleh barang berkualitas buruk.

Menurut Myers dan Majluf (1984), ada asimetri informasi antara manajer dengan investor, manajer mempunyai informasi yang lebih lengkap mengenai kondisi perusahaan dibandingkan dengan investor. Penelitian Dierkens (1991) menunjukkan bahwa asimetri informasi merupakan variabel yang signifikan dalam penerbitan saham. Konsekuensi dari asimetri informasi adalah ketidakseimbangan dalam transaksi yang dapat menyebabkan kekacauan dalam transaksi (Lin dan Tian, 2012).

Beberapa literatur menjelaskan terjadinya underpricing karena adanya asimetri informasi. Model Rock (1986) mengemukakan adanya asimetri informasi antara investor yang memiliki informasi dan investor yang tidak memiliki informasi. Penelitian Beatty (1989) menjelaskan asimetri informasi dapat terjadi antara emiten dengan underwriter, maupun antar investor. Model Baron (1982) menjelaskan bahwa semakin besar ketidakpastian emiten mengenai harga sahamnya, maka lebih besar permintaan terhadap jasa underwriter dalam menetapkan harga. Konpensasi atas informasi yang diberikan underwriter adalah dengan mengizinkan underwriter menawarkan harga perdana sahamnya dibawah harga keseimbangan. Dengan demikian, semakin besar ketidakpastian akan semakin besar risiko yang dihadapi underwriter, maka akan menyebabkan tingkat underpricing semakin tinggi (Herawati et al, 2016).

Terdapat dua cara dalam mencegah permasalahan yang ditimbulkan akibat asimetri informasi yaitu signalling dan screening. Signalling theory mengungkapkan bahwa untuk mengurangi asimetri informasi adalah dengan cara memberikan informasi kepada publik (Godfrey et al, 2010). Sementara menurut screening theory, pihak dengan informasi lebih rendah akan mempelajari kebiasaan pihak lain untuk mengurangi ketidaktahuan informasi tentang pihak tersebut (Spence, 1973). Dalam proses pelaksanaan IPO, terdapat proses yang dapat mengurangi asimetri informasi seperti menerbitkan laporan keuangan berkualitas yang bertujuan untuk memberikan informasi mengenai perusahaan kepada calon investor.

Penelitian ini merupakan replikasi dari penelitian yang dilakukan oleh Lin dan Tian (2012) pada bursa saham China menunjukkan bahwa konservatisme akuntansi berpengaruh negatif terhadap underpricing saham IPO. Penelitian tersebut juga menunjukkan bahwa pengaruh negatif tersebut akan semakin terlihat jika asimetri informasi tinggi. Adapun perbedaan yang terdapat dalam penelitian ini dengan penelitian sebelumnya yaitu penelitian dilakukan dengan memasukkan semua sektor industri yang terdaftar di Bursa Efek Indonesia pada tahun 2015-2018, hal ini dilakukan agar hasil penelitian memiliki tingkat validitas yang lebih baik. Penelitian kali ini akan mencoba menguji dampak konservatisme akuntansi terhadap tingkat underpricing saham saat IPO pada emiten yang tercatat di Bursa Efek Indonesia dengan melihat apakah asimetri informasi mempengaruhi dampak tersebut.

\section{REVIU LITERATUR DAN PENGEMBANGAN HIPOTESIS Signaling Theory}

Menurut Wolk et al (2001) teori sinyal memaparkan alasan perusahaan manyajikan informasi untuk pasar modal. Teori sinyal menunjukkan adanya asimetri informasi antara manajemen dengan pihak-pihak yang berkepentingan dengan informasi tersebut. Dalam teori sinyal, pengeluaran investasi memberikan sinyal positif tentang pertumbuhan perusahaan dimasa yang akan datang, sehingga meningkatkan harga saham sebagai indikator nilai perusahaan. Welch dan Ritter (2002) menjelaskan peranan teori sinyal dalam fenomena underpricing. Underpricing pada saat IPO adalah mekanisme perusahaan dalam memberikan sinyal tentang kualitas 
perusahaan. perusahaan dengan kualitas baik melakukan underpricing saham katika mereka melakukan penawaran saham.

\section{Underpricing}

Underpricing digunakan untuk menggambarkan perbedaan harga penawaran saham di pasar perdana dengan harga saham pada pasar sekunder pada hari pertama perdagangan (Beatty R, 1989). Fenomena underpricing ini seringkali terjadi dalam IPO. Terdapatnya kecendrungan pada harga penawaran di pasar perdana selalu lebih rendah dibandingkan dengan harga penutupan di hari pertama pasar sekunder. Sedangkan overpricing, merupakan fenomena harga penawaran di pasar perdana lebih tinggi daripada harga penutupan hari peratama di pasar sekunder. Underpricing adalah biaya yang tidak langsung dari perusahaan yang melakukan IPO. Artinya jika harga saham dapat diterima di pasar dengan harga yang lebih tinggi, kenapa tidak dijual dengan harga tersebut, yaitu sama dengan harga penutupan hari pertama di pasar sekunder. Pemilik menginginkan agar underpricing ini ditekan karena terjadinya fenomena ini akan menyebabkan transfer kemakmuran dari pemilik kepada investor (Beatty, 1989).

\section{Konservatisme Akuntansi}

Konservatisme didefinisikan sebagai kecendrungan akuntan untuk melakukan verifikasi yang tinggi terhadap pembukuan laba, dibandingkan rugi (Basu, 1997). Sementara pendapat lain mengartikan konservatisme akuntansi sebagai preferensi untuk memilih metode akuntansi yang menghasilkan nilai rendah dari sisi pendapatan dan aset serta nilai yang tinggi untuk sisi liabilitas dan beban sehingga menghasilkan ekuitas yang kecil (Wolk dan Tearney, 2000). Dalam kerangka konseptual, konservatisme akuntansi didefinisikan sebagai pemilihan keputusan yang tidak menaikan aset atau laba ketika berada dalam situasi yang meragukan (Kisoe, 2009). Sementara itu pendapat lain mengatakan bahwa konservatisme akuntansi merupakan pilihan manajemen ketika berada dalam keragu-raguan untuk menggunakan motode pencatatan yang memiliki keungkinan paling kecil dalam overstating aset perusahaan (Schroeder, 2001).

\section{Asimetri Informasi}

Asimetri informasi didefinisikan sebagai perbedaan informasi yang dimiliki oleh agent dan principal, yang mengakibatkan agent mempunyai informasi lebih dibandingkan dengan principal yang mengakibatkan principal tidak dapat mengetahui kinerja yang sesungguhnya dari perusahaan yang dikelola oleh agent (Kaplan dan Alkinson, 1998). Asimetri informasi dinilai merugikan principal dikarenakan mereka merupakan pemilik modal namun mereka menginvestasikan modal mereka pada keadaan yang tidak sesuai dengan informasi yang ada. Asimetri informasi tersebut bisa membuat agent melakukan tindakan yang tidak sesuai dengan kehendak principal.

Asimetri informasi dapat membuat konflik antara agent dengan principal karena mereka mempunyai tujuan yang berbeda dalam memaksimalkan utilitas masing-masing. Terdapat tiga asumsi dasar dari sifat manusia yaitu mementingkan diri sendiri, manusia memiliki pandangan terbatas mengenai persepsi masa depan, dan manusia cendrung risk averse (Eisenhardt, 1989). Berdasarkan teori tersebut menyebabkan informasi yang diberikan untuk pihak lain akan selalu dipertanyakan keandalannya mengenai informasi yang disampaikan. Implikasi dari adanya asimetri informasi adalah terjadinya dua masalah yaitu adverse selection dan moral hazard (Scoot, 2000). 


\section{Pengaruh Konservatisme Akuntansi terhadap Underpricing Saham IPO}

Penerapan prinsip konservatisme dalam pelaporan keuangan akan menguntungkan pemilik dan dapat meningkatkan nilai perusahaan (Lin dan Tian, 2012). Kim dan Pevzner (2010) menunjukkan bahwa laporan keuangan yang konservatif akan memberikan informasi kepada pemegang saham berupa berkurangnya kemungkinan berita buruk pada masa mendatang. Selain manfaat tersebut Lafond dan Watts (2008) berpendapat bahwa penerapan prinsip konservatisme akuntansi diharapkan untuk menurunkan asimetri informasi antara manajer dengan investor luar. Asimetri informasi yang terjadi akan menguntungkan manajer, karena mereka dapat menggunakan informasi yang dimilikinya untuk mentransfer kekayaan dari investor ke diri mereka sendiri dengan menyatakan kinerja keuangan yang berlebihan selama masa jabatan mereka diperusahaan (Lafond dan Watts, 2008).

Konservatisme akuntansi dapat mengurangi asimetri informasi antara manajer dengan investor dengan cara konservatisme akuntansi dapat memberikan informasi mengenai kinerja perusahaan saat ini yang dapat diandalkan kepada investor (Lafond dan Watts, 2008). Dengan cara ini, investor luar akan mengetahui nilai sebenarnya perusahaan dan informasi yang tidak diinformasikan oleh perusahaan dan penjamin emisi. Dengan demikian asimetri informasi antara pelaku IPO dapat dikurangi dengan penerapan konservatisme akuntansi dan tingkat underpricing pada saat IPO juga akan berkurang (Lin dan Tian, 2012)

H1: Konservatisme akuntansi berpengaruh negatif terhadap underpricing saham IPO.

\section{Pengaruh Konservatisme Akuntansi terhadap Underpricing Saham IPO Akan Lebih Terlihat Ketika Asimetri Informasi Tinggi.}

Asimetri informasi memperburuk masalah keagenan antara pemilik dengan agen (Haw dan Lee, 2010). Pihak-pihak yang memiliki informasi lebih, akan memiliki peluang untuk mentransfer kekayaan dari investor kepada diri mereka sendiri. Kecendrungan ini lebih besar untuk perusahaan yang akan melakukan IPO yang saham perusahaannya hanya dimiliki oleh beberapa pihak saja (Burkart, Gromb, dan Panunzi, 1997; Mueller dan Inderst, 2001). Oleh karena itu, para manajer di perusahaan-perusahaan ini memiliki kebebasan yang lebih besar untuk mementingkan kepentingan sendiri dan mengorbankan kepentingan pemegang saham (Francis dan Martin, 2010). Lafond dan Watts (2008) berpendapat bahwa manajer dapat menurunkan harga saham perusahaan dan meningkatkan tingkat pengembalian dan akhirnya menghasilkan biaya agensi yang dapat mengurangi arus kas yang diharapkan oleh perusahaan. Semakin banyak informasi yang dimiliki oleh manajer, maka semakin besar bid ask spread dan semakin rendah return yang diterima oleh investor luar (Amihud dan Mendelson, 1986).

Untuk menghindari hal tersebut, hal yang harus dilakukan oleh pemegang saham adalah dengan meningkatkan informasi perusahaan kepada publik (Lafond dan Watts, 2008). Investor lebih menyukai perusahaan yang memiliki informasi yang dapat diverifikasi dan tidak ada manipulasi laporan dari manajemen. Akibatnya asimetri informasi antara manajer dengan investor menuntut adanya penerapan prinsip konservatisme akuntansi. Perusahaan yang memiliki asimetri informasi tinggi maka konservatisme akuntansi memainkan peran yang lebih signifikan dalam membatasi manipulasi laporan oleh manajemen (Garcia, et al, 2009). Maka dapat ditarik kesimpulan bahwa penerapan prinsip konservatisme akuntansi lebih dibutuhkan ketika asimetri informasi tinggi.

H2 : Hubungan negatif antara konservatisme akuntansi dengan underpricing saham IPO lebih terlihat untuk perusahaan dengan asimetri informasi tinggi daripada perusahaan dengan asimetri informasi rendah. 


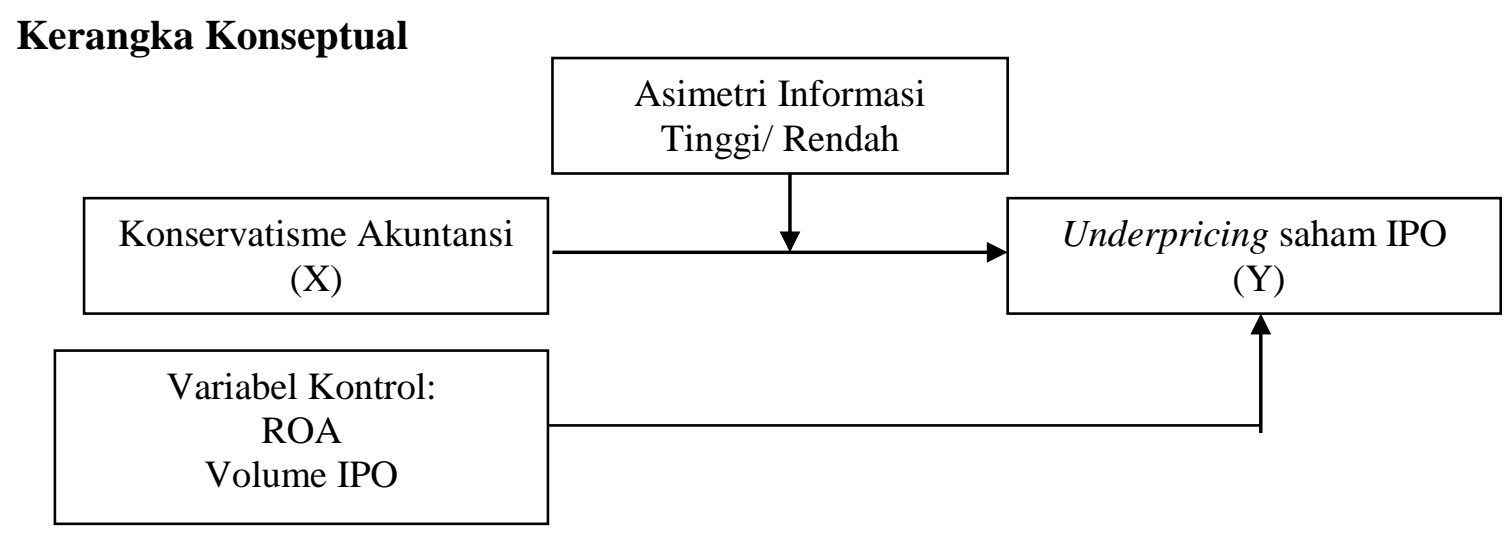

\section{Gambar 1. Kerangka Konseptual}

\section{METODE PENELITIAN}

Jenis penelitian ini tergolong penelitian kausatif. Penelitian kausatif merupakan penelitian yang menganalisis pengaruh antar variabel dependen dan variabel independen. Dalam penelitian ini akan menjelaskan pengaruh konservatisme akuntansi terhadap underpricing saham IPO dengan asimetri informasi sebagai variabel moderating. Objek penelitian adalah semua perusahaan yang melakukan IPO (Initial Public Offering) dan mengalami underpricing pada tahun 2015-2018 di Bursa Efek Indonesia.

Populasi penelitian ini adalah semua perusahaan yang melakukan Initial Public Offering (IPO) pada tahun 2015-2018 di Bursa Efek Indonesia. Sedangkan sampel yang digunakan dalam penelitian ini menggunakan metode purposive sampling. Menurut Suharyadi (2009) metode purposive adalah penarikan sampel dengan pertimbangan tertentu. Pertimbangan tersebut berdasarkan pada tujuan serta kepentingan penelitian. Data yang digunakan dalam penelitian ini adalah data sekunder. Data sekunder adalah data yang diperoleh dari sumber-sumber lain, seperti buku dan bacaan lainnya, hasil analisis pasar yang berhubungan dengan masalah yang diteliti. Teknik analisis data dalam penelitian ini menggunakan analisis regresi moderasi dengan jumlah data adalah 97. Model persamaan regresi moderasi dalam penelitian ini adalah sebagai berikut:

$$
\mathrm{UP}=\beta 0+\beta_{1} \mathrm{CONS}+\beta_{2} \mathrm{ROA}+\beta_{3} \mathrm{VOL}+\epsilon
$$

\section{Variabel Penelitian \& Pengukurannya \\ Underpricing Saham IPO}

Penilaian tingkat underpricing suatu perusahaan dapat dilihat dari kenaikan harga saham perusahaan ketika hari pertama masuk ke pasar sekunder. Proksi untuk mengukur tingkat underpricing dalam penelitian ini menggunakan proksi market-adjustded abnormal return yang digunakan dalam penelitian Anggrarwal, Leal, dan Hernandez (2013). Perhitungan menggunakan metode market-adjustded abnormal return (MAAR) dinilai lebih objektif dalam mengukur tingkat underpricing. Perhitungan mengenai tingkat underpricing saham adalah sebagai berikut:

Keterangan:

$$
\text { MAAR }=100 X[(1+\mathrm{Ri}] /[(1+\mathrm{Rm})]-1
$$

MAAR = Market-adjustded abnormal return

$\mathrm{Ri} \quad=$ Imbal hasil saham pada hari pertama (dalam persen)

$\mathrm{Rm}=$ Imbal hasil pasar pada hari pertama dicatatkannya saham di Bursa Efek Indonesia 
Untuk menghitung imbal hasil saham pada hari pertama (Ri) adalah dengan melihat perbedaan harga antara saham pada saat IPO dengan harga saham emiten pada penutupan hari pertama perdagangan di pasar sekunder. Dari data harga saham pada sat IPO didapatkan dari prospectus IPO emiten, sedangkan untuk data harga penutupan bersumber dari data transaksi saham di Bursa Efek Indonesia. Untuk menghitung imbal hasil pasar ( $\mathrm{Rm})$ adalah dengan membandingkan perubahan poin pada indeks di Bursa Efek Indonesia pada pembukaan perdagngan hingga penutupan perdagangan. Tanggal pengambilan imbal hasil pasar ( $\mathrm{Rm})$ disesuaikan dengan tanggal emiten saat hari pertama kali masuk ke pasar sekunder. Untuk sumber data berasal dari data transaksi saham Bursa Efek Indonesia.

\section{Konservatisme Akuntansi}

Variabel independen dalam penelitian ini adalah konservatisme akuntansi. Untuk mengukur konservatisme akuntansi digunakan metode accrual based measure of conservatism (Givoly dan Hayn, 2000). Pengukuran dari metode tersebut adalah total akrual dari perusahaan yang dibagi dengan total aset diawal tahun sebelum IPO. Berikut merupakan perhitungan dari total akrual:

$$
\text { Total akrual }=([(\text { Laba bersih }+ \text { Depresiasi })-\text { Arus Kas dari operasi }] / \text { Total Aset }) X-1
$$

Pemilihan proksi mengguankan total akrual dipilih dikarenakan ketersediaan data, dikarenakan hanya beberapa perusahaan yang mempublikasikan laporan keuangan 2 tahun sebelum melaksanakan IPO. Dengan menggunakan pendekatan total akrual data yang digunakan hanyalah data satu tahun sebelum IPO yang tersedia pada laporan keuangan.

\section{Asimetri Informasi}

Variabel moderating dalam penelitian ini adalah asimetri informasi. Dalam penelitian ini semua emiten akan dibagi menjadi dua kelompok yaitu emiten dengan tingkat asimetri informasi tinggi atau rendah, dan menganalisis apakah hubungan antara konservatisme akuntansi dengan underpricing lebih terlihat ketika asimetri informasi tinggi. Proksi yang digunakan untuk menilai asimetri informasi dalam penelitian ini adalah (Lin dan Tian, 2012):

1. Umur Perusahaan

Perusahaan yang lebih muda cenderung memiliki lebih banyak opsi pertumbuhan dan sistem akuntansi dan pelaporan yang kurang terstandarisasi dibandingkan dengan perusahaan lama, dan memiliki skala asimetri informasi yang lebih besar (Stoll dan Curley, 1970). Umur perusahaan diukur dengan melihat lama tahun perusahaan berdiri sampai melakukan IPO.

2. Ukuran Perusahaan

Perusahaan besar lebih matang dan memiliki lingkungan informasi yang lebih kaya dan berkontribusi terhadap ketidakpastian dan asimetri informasi secara keseluruhan yang tekait dengan realisasi keuntungan yang diproyeksikan. Ukuran perusahaan diukur dengan melihat total aset sebelum IPO.

Dalam penelitian ini, sampel akan dibagi menjadi dua, yaitu sampel dengan asimetri informasi tinggi, dan sampel dengan asimetri rendah. Perusahaan/sampel dengan usia muda dan ukuran perusahaan kecil diklasifikasikan sebagai perusahaan dengan asimetri informasi tinggi. Sedangkan usia yang tua dan ukuran perusahaan besar akan diklasifikasikan sebagai perusahaan dengan asimetri rendah. 


\section{Variabel Kontrol}

Variabel kontrol yang digunakan dalam penelitian ini untuk melihat pengaruh dari variabel-variabel lain atas variabel dependen diatas adalah return on assets dan jumlah IPO di BEI. Berikut penjelasan dari variabel-variabel kontrol:

a. Return On Assets (ROA)

Return on assets digunakan dalam penelitian ini untuk menjadi variabel kontrol. ROA merupakan salah satu cara mengukur tingkat profitabilitas suatu perusahaan. Tingkat profitabilitas dapat menjadi faktor yang mengurangi dampak negatif dari underpricing pada saat IPO (Lin dan Tian, 2012). ROA dihitung dengan membandingkan laba bersih perusahaan dengan total aset perusahaan. Secara matematis formula untuk menghitung ROA adalah:

$$
\text { ROA = Laba bersih / Total Aset }
$$

Laba bersih yang digunakan dalam perhtungan ROA adalah laba setelah pajak setahun sebelum emiten melakukan IPO. Data dari laba setelah pajak didapatkan dari laporan laba/rugi perusahaan.

b. Jumlah IPO

Jumlah IPO merupakan volume dari total perusahaan yang mencatatkan sahamnya di Bursa Efek Indonesia pada satu tahun periode. Berdasarkan fenomena "hot issue" menyebutkan bahwa jumlah IPO akan berpengaruh positif terhadap tingkat underpricing (Lin dan Tian, 2012).

\section{HASIL DAN PEMBAHASAN Analisis Deskrptif}

Tabel 1. Hasil Deskripsi Statistik

\begin{tabular}{|l|c|c|c|c|}
\hline \multirow{2}{*}{ Mean } & UP & CONS & ROA & VOL \\
\cline { 2 - 5 } Median & 54172.42 & -0.389278 & 7.416804 & 40.63918 \\
Maximum & 51044.00 & -0.009000 & 3.200000 & 36.00000 \\
Minimum & 97145.00 & 103.5740 & 168.0200 & 56.00000 \\
Std. Dev. & 8805.000 & -105.3760 & -129.2400 & 13.00000 \\
Observations & 24599.15 & 15.46793 & 30.38742 & 17.07897 \\
\hline
\end{tabular}

(Sumber: Data Olahan Eviews9 Tahun 2020)

Berdasarkan tabel 1 diatas, variabel UP (Underpricing) sebagai variabel dependen (Y) pada tahun 2015-2018 memiliki rata-rata sebesar 54172,42 (54,172\%) dengan standar deviasi 24599.15. Nilai UP maksimum sebesar 97145.00 (97,145\%) dan nilai minimum sebesar 8805.00 $(8,805 \%)$. Variabel Konservatisme Akuntansi (CONS) sebagai variabel independen (X) pada IPO tahun 2015-2018 memiliki rata-rata sebesar -0,389278 artinya rata-rata perusahaan tidak konservatif dalam pelaporan keuangannya. Nilai CONS tertinggi dengan angka 103.5740 dan terendah adalah $-105,3760$.

Variabel kontrol terdiri dari dua, yaitu Return On Assets (ROA) dan Volume IPO. Return On Assets (ROA) memiliki rata-rata 7.416804 dengan standar deviasi 30.38742. Nilai ROA maksimum sebesar 168.0200 dan minimum sebesar -129.2400. Sedangkan volume IPO memiliki rata-rata 40.63918 artinya sebanyak 40.63918 perusahaan yang melakukan IPO 
pertahunnya dari tahun 2015-2018. Standar deviasi variabel volume IPO adalah sebesar 17.07897 dan nilai maksimum nya adalah 56 dan nilai terendah sebesar 13 .

\section{Analisis Induktif \\ Hipotesis pertama}

Dalam penelitian ini, hipotesis pertama yaitu konservatisme akuntansi berpengaruh negatif terhadap underpricing saham IPO. Tabel dibawah ini menunjukkan hasil regresi pada hipotesis pertama:

Tabel 2. Regresi Linear

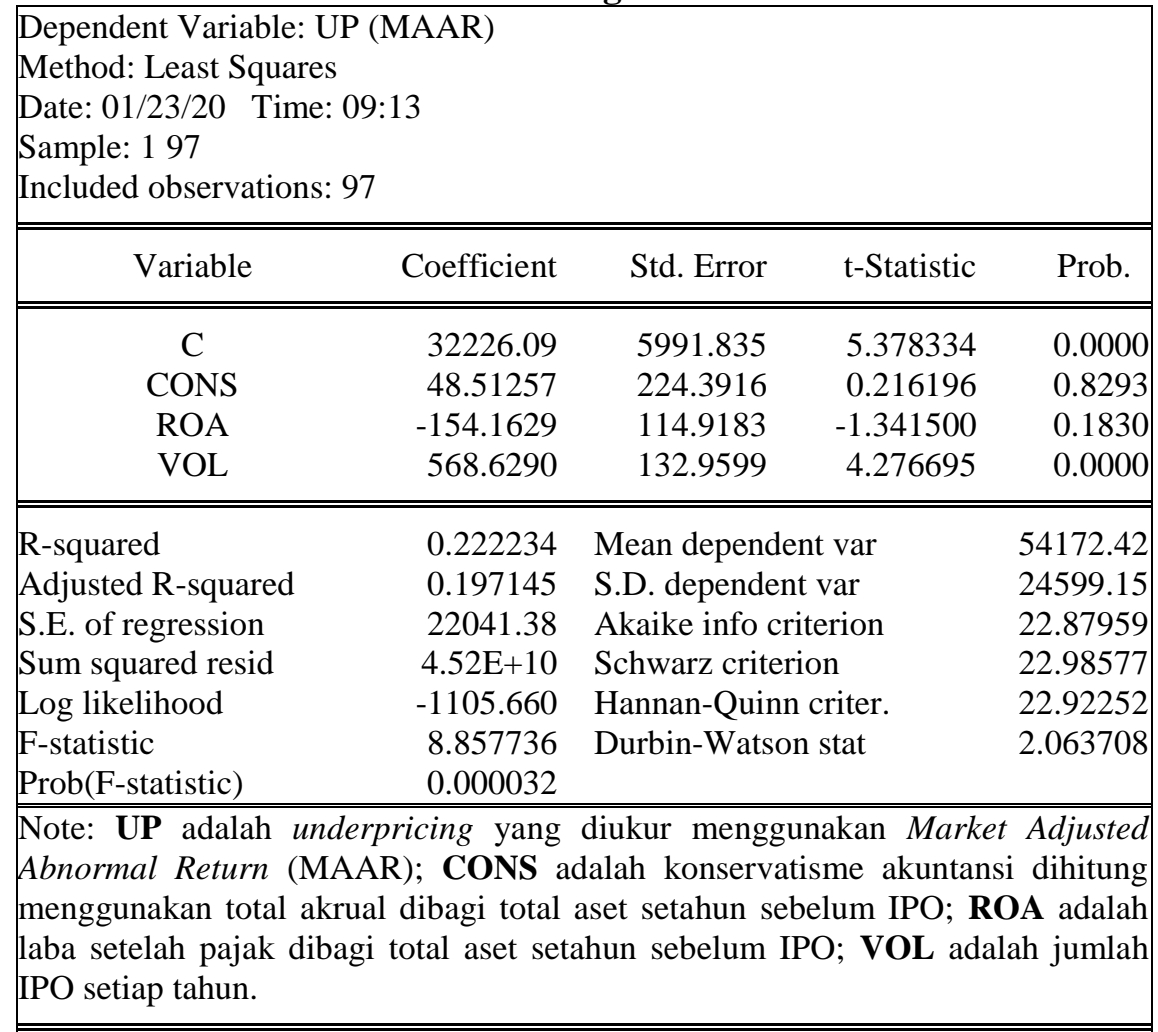

(Sumber: Data Olahan Eviews9 Tahun 2020)

Berdasarkan tabel 2 diatas, dapat dilihat bahwa model dengan variabel dependen UP memiliki nilai probabilitas $\mathrm{F}$ sebesar 00000 yang lebih kecil dari tingkat alpha yakni 0.05 . Nilai tersebut menunjukkan bahwa model yang digunakan sudah tepat pada tingkat keyakinan $99 \%$. Dari regresi tersebut dapat disimpulkan bahwa variabel-variabel bebas yang digunakan dalam model secara global memiliki pengaruh yang signifikan dengan variabel dependen berupa market adjusted abnormal return (MAAR). Berdasarkan tabel 12 diatas, diketahui nilai koefisien regresi variabel konservatisme akuntansi (CONS) yang sebesar 48.51257. Berarti konservatisme akuntansi berpengaruh positif terhadap tingkat underpricing. Nilai koefesien regresi ROA adalah -154.1629 yang menunjukkan return on assets memiliki pengaruh negatif terhadap tingkat underpricing. Nilai koefesien regresi VOL adalah sebesar 568.6290 yang menunjukkan jumlah IPO memiliki pengaruh positif terhadap tingkat underpricing. Hasil Adj R-Square sebesar 0.197145, yang berarti seluruh variabel bebas berpengaruh terhadap underpricing sebesar 0.197145 atau $19 \%$. 


\section{Hipotesis Kedua}

Dalam penelitian ini, hipotesis kedua yaitu pengaruh konservatisme akuntansi terhadap underpricing saham IPO akan lebih terlihat ketika asimetri informasi tinggi. Tabel dibawah ini menunjukkan hasil regresi pada perusahaan yang memiliki asimetri informasi tinggi:

\section{Asimetri Informasi Tinggi}

Tabel 3. Regresi Linear ke-1 Hipotesis 2

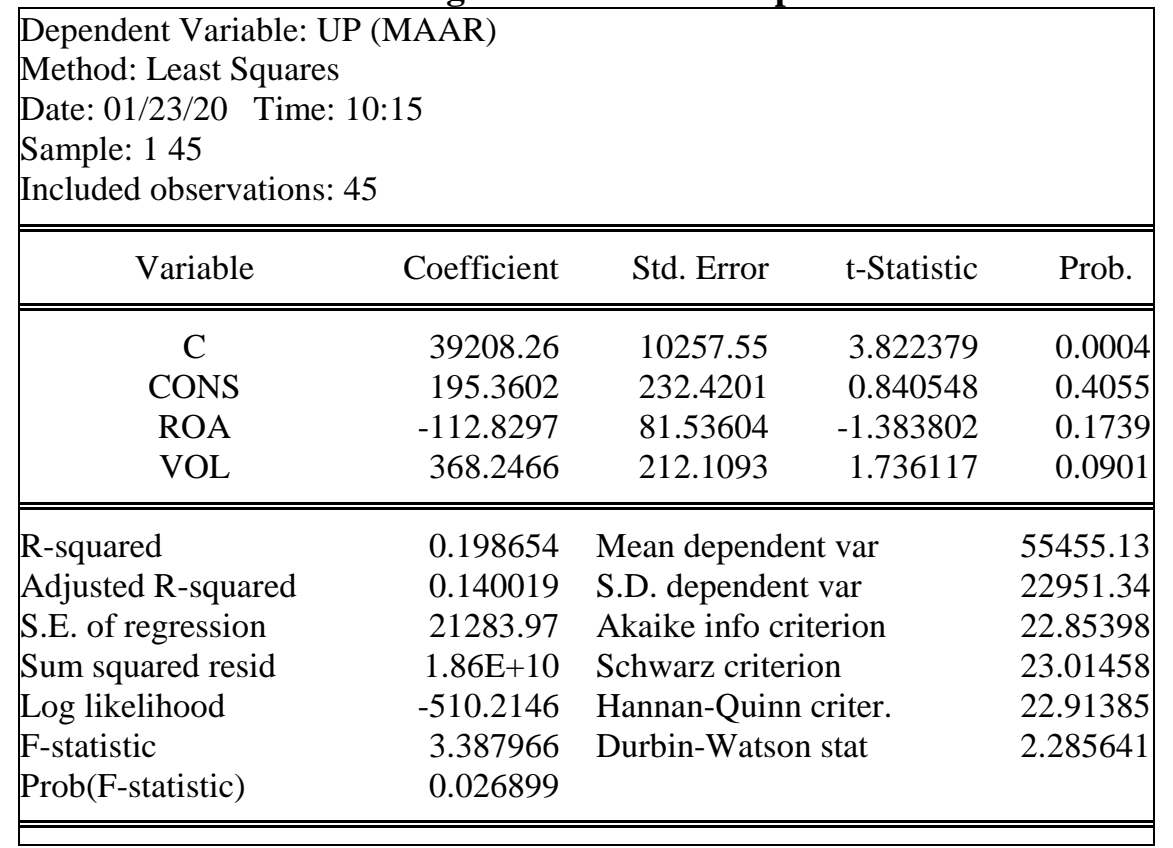

(Sumber: Data Olahan Eviews9 Tahun 2020)

Pada tabel 3, sampel yang diuji merupakan sampel yang memiliki asimetri informasi tinggi yaitu sebanyak 45 sampel. Dari hasil regresi diatas, dapat dilihat nilai koefisien regresi variabel konservatisme akuntansi (CONS) terhadap underpricing sebesar 195.3602 kearah positif. Nilai koefesien regresi ROA adalah -112.8297 yang menunjukkan return on assets memiliki pengaruh negatif terhadap tingkat underpricing. Nilai koefesien regresi VOL adalah sebesar 368.2466 yang menunjukkan jumlah IPO memiliki pengaruh positif terhadap tingkat underpricing. Hasil Adj R-Square sebesar 0.140019, yang berarti seluruh variabel bebas berpengaruh terhadap underpricing sebesar 0.140019 atau $14 \%$.

\section{Asimetri Informasi Rendah}

Pada tabel 4, sampel yang diuji merupakan sampel yang memiliki asimetri informasi rendah yaitu sebanyak 16 sampel. Dari hasil regresi diatas, dapat dilihat nilai koefisien regresi variabel konservatisme akuntansi (CONS) terhadap underpricing sebesar 138936.3 yang lebih besar dari regresi pertama pada hipotesis kedua sebesar 195.3602 yang berarti pengaruh positif yang dihasilkan lebih besar pada regresi kedua ini. Nilai koefesien regresi ROA adalah 548.0384 yang menunjukkan return on assets memiliki pengaruh negatif yang lebih terhadap tingkat underpricing dibandingkan regresi pertama. Nilai koefesien regresi VOL adalah sebesar 494.2548 yang menunjukkan jumlah IPO memiliki pengaruh positif yang lebih sedikit terhadap 
tingkat underpricing dibandingkan regresi pertama. Hasil Adj R-Square sebesar 0.101188, yang berarti seluruh variabel bebas berpengaruh terhadap underpricing sebesar 0.101188 atau 10 .

Tabel 4. Regresi Linear ke-2 Hipotesis 2

\begin{tabular}{|c|c|c|c|c|}
\hline \multicolumn{5}{|c|}{$\begin{array}{l}\text { Dependent Variable: UP (MAAR) } \\
\text { Method: Least Squares } \\
\text { Date: 01/27/20 Time: } 19: 16 \\
\text { Sample: } 16 \\
\text { Included observations: } 16\end{array}$} \\
\hline Variable & Coefficient & Std. Error & t-Statistic & Prob. \\
\hline $\mathrm{C}$ & 37612.85 & 16096.74 & 2.336674 & 0.037 \\
\hline CONS & 138936.3 & 88645.45 & 1.567326 & 0.1430 \\
\hline ROA & -548.0384 & 999.4794 & -0.548324 & 0.5935 \\
\hline VOL & 494.2548 & 411.1875 & 1.202018 & 0.2525 \\
\hline R-squared & 0.280951 & \multicolumn{2}{|c|}{ Mean dependent var } & 49099.69 \\
\hline Adjusted R-squared & 0.101188 & \multicolumn{2}{|c|}{ S.D. dependent var } & 29211.71 \\
\hline S.E. of regression & 27694.36 & \multicolumn{2}{|c|}{ Akaike info criterion } & 23.50816 \\
\hline Sum squared resid & $9.20 \mathrm{E}+09$ & \multicolumn{2}{|c|}{ Schwarz criterion } & 23.70131 \\
\hline Log likelihood & -184.0653 & \multicolumn{2}{|c|}{ Hannan-Quinn criter. } & 23.51805 \\
\hline F-statistic & 1.562901 & \multirow{2}{*}{\multicolumn{2}{|c|}{ Durbin-Watson stat }} & 1.299972 \\
\hline Prob(F-statistic) & 0.249537 & & & \\
\hline
\end{tabular}

(Sumber: Data Olahan Eviews9 Tahun 2020)

\section{Uji Asumsi Klasik}

\section{Uji Normalitas}

Tujuan dari uji normalitas ini adalah untuk menguji dalam sebuah model regresi, variabel dependen dan variabel independen terdistribusi secara normal atau tidak. Dari gambar 2 dibawah dapat dilihat bahwa residual data terdistribusi normal dimana nilai probabilitasnya $>$ a $(0,05)$ yaitu $0.410719>0,05$.
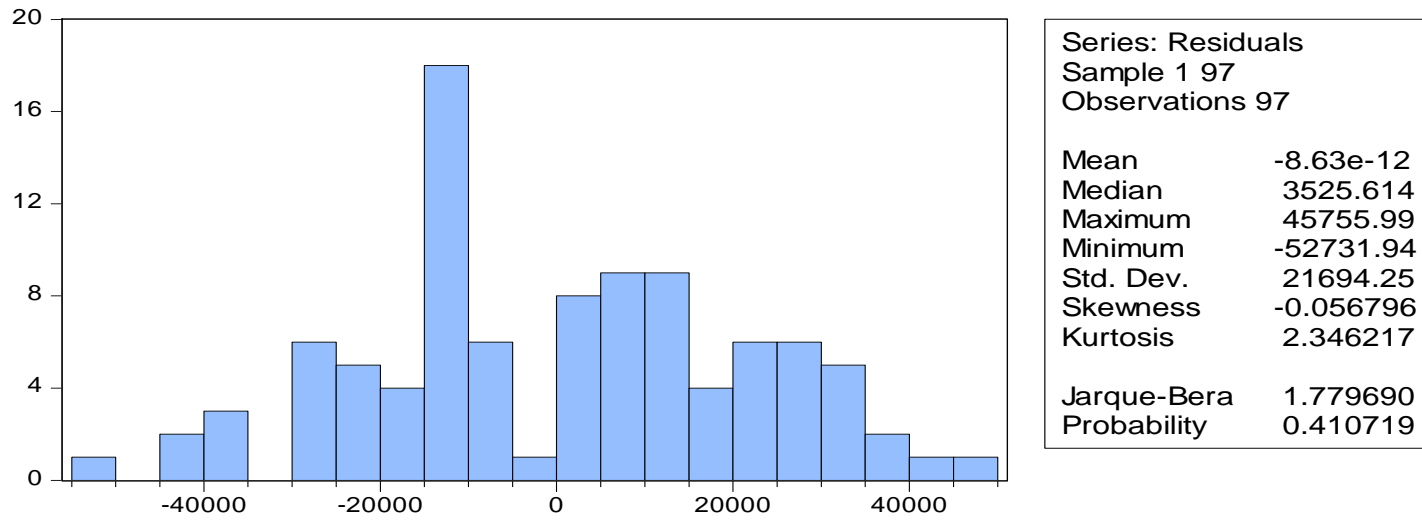

Gambar 2. Hasil Uji Normalitas 


\section{Uji Multikolinieritas}

Gejala multikolinieritas ditandai dengan adanya hubungan yang kuat diantara variabel independen dalam suatu persamaan regresi. Apabila dalam suatu persamaan regresi terdapat gejala multikolinieritas, maka akan menyebabkan ketidakpastian estimasi, sehingga kesimpulan yang diambil tidak tepat. Model regresi yang dinyatakan bebas dari multikolinieritas apabila nilai VIF < 10. Hasil Uji multikolinieritas dapat dilihat pada tabel kolom Centered VIF. Nilai VIF untuk variabel CONS sebesar 2.380518, nilai variabel ROA adalah 2.409684 dan nilai VIF untuk variabel VOL sebesar 1.018964. Karena nilai VIF dari ketiga variabel tersebut tidak ada yang lebih besar dari 10, maka dapat dikatakan tidak terjadi multikolinieritas pada ketiga variabel bebas tersebut.

\section{Tabel 5. Hasil Uji Multikolinieritas}

Variance Inflation Factors

Date: 01/23/20 Time: 09:07

Sample: 197

Included observations: 97

\begin{tabular}{cccc}
\hline \hline Variable & $\begin{array}{c}\text { Coefficient } \\
\text { Variance }\end{array}$ & $\begin{array}{c}\text { Uncentered } \\
\text { VIF }\end{array}$ & $\begin{array}{c}\text { Centered } \\
\text { VIF }\end{array}$ \\
\hline \hline C & 35902082 & 7.168262 & NA \\
CONS & 50351.60 & 2.382041 & 2.380518 \\
ROA & 13206.23 & 2.554730 & 2.409684 \\
VOL & 17678.34 & 6.848386 & 1.018964 \\
\hline \hline
\end{tabular}

(Sumber: Data Olahan Eviews9 Tahun 2020)

\section{Uji Heteroskedastisitas}

Heteroskedastisitas digunakan untuk menguji apakah dalam sebuah model regresi terjadi ketidaksamaan varians dalam residual dari suatu pengamatan kepengamatan lainnya. Untuk mendeteksi adanya heteroskedastisitas digunakan uji Glejser. Apabila nilai nilai probabilitas Chi-Square dari $O b s * R$-Square > a (0.05) maka tidak terdapat gejala heteroskedastisitas. Berdasarkan tabel 10 dibawah, probabilitas Chi-Square dari Obs*R-Square adalah 0.5960 yang > 0.05 yang menunjukkan tidak ada gejala heteroskedastisitas.

Tabel 6. Hasil Uji Heteroskedastisitas

Heteroskedasticity Test: Glejser

\begin{tabular}{llll}
\hline \hline F-statistic & 0.615334 & Prob. F(3,93) & 0.6068 \\
Obs*R-squared & 1.887925 & Prob. Chi-Square(3) & 0.5960 \\
Scaled explained SS & 1.387987 & Prob. Chi-Square(3) & 0.7084 \\
\hline \hline
\end{tabular}

(Sumber: Data Olahan Eviews9 Tahun 2020)

\section{Uji Autokorelasi}

Uji autokorelasi merupakan pengujian asumsi dalam regresi dimana variabel dependen tidak berkolerasi dengan dirinya sendiri. Maksud korelasi dengan diri sendiri adalah bahwa nilai dari variabel dependen tidak berhubungan dengan variabel itu sendiri, baik nilai periode sebelumnya maupun nilai sesudahnya. Penelitian ini menggunakan metode Brusch-Godfrey 
Serial Correlation LM Test. Jika nilai Prob F hitung lebih besar dari tingkat alpha 0.05 (5\%) maka H0 diterima yang artinya tidak terjadi autokorelasi. Sebaliknya jika Prob F hitung lebih kecil dari 0.05 maka dapat disimpulkan terjadi autokorelasi. Berikut adalah tabel hasil uji autokorelasi yang menunjukkan nilai Prob F sebesar 0.8255 yang nilai tersebut lebih besar dari tingkat alpha 0.05 sehingga dapat disimpulkan berdasarkan uji hipotesis H0 diterima yang artinya tidak terjadi autokorelasi.

Tabel 7. Uji Autokorelasi

Breusch-Godfrey Serial Correlation LM Test:

\begin{tabular}{llll}
\hline \hline F-statistic & 0.180649 & Prob. F(2,91) & 0.8350 \\
Obs*R-squared & 0.383597 & Prob. Chi-Square(2) \\
\hline \hline
\end{tabular}

(Sumber: Data Olahan Eviews9 Tahun 2020)

\section{Uji Model}

\section{Koefesien Determinan $\left(\mathbf{R}^{\mathbf{2}}\right)$}

Berdasarkan hasil regresi pada tabel 11, nilai adjusted $R$-Square sebesar 19\%. Hal ini mengindikasikan bahwa kontribusi variabel independen terhadap variabel dependen dalam hipotesis pertama hanya sebesar $19 \%$ dan sebesar $81 \%$ ditentukan oleh varibel lain yang tidak dianalisis dalam model penelitian ini. Berdasarkan hasil regresi pada tabel 12 , nilai adjusted $R$ Square sebesar $14 \%$.

Hal ini mengindikasikan bahwa kontribusi variabel independen terhadap variabel dependen dalam hipotesis kedua hanya sebesar $14 \%$ dan sebesar $86 \%$ ditentukan oleh varibel lain yang tidak dianalisis dalam model penelitian ini. Berdasarkan hasil regresi pada tabel 13, nilai adjusted $R$-Square sebesar $10 \%$. Hal ini mengindikasikan bahwa kontribusi variabel independen terhadap variabel dependen dalam hipotesis pertama hanya sebesar $10 \%$ dan sebesar 90\% ditentukan oleh varibel lain yang tidak dianalisis dalam model penelitian ini.

\section{Uji Signifikan Simultan (Uji F)}

Berdasarkan tabel 11, diketahui bahwa probabilitas $($ F-Statistic $)>0.05=8.857736>$ 0.05. Hal ini menandakan bahwa model regresi diterima atau model regresi ini menunjukkan tingkatan yang baik (good overall model fit) sehingga model regresi dapat digunakan mengukur pengaruh konservatisme akuntansi terhadap underpricing saham IPO. Berdasarkan tabel 12, diketahui bahwa probabilitas $(F$-Statistic $)>0.05=3.387966>0.05$.

Hal ini menandakan bahwa model regresi diterima atau model regresi ini menunjukkan tingkatan yang baik (good overall model fit) sehingga model regresi dapat digunakan mengukur pengaruh konservatisme akuntansi terhadap underpricing saham IPO dalam kondisi asimetri informasi tinggi. Berdasarkan tabel 13, diketahui bahwa probabilitas (F-Statistic) $>0.05=$ $1.562901>0.05$. Hal ini menandakan bahwa model regresi diterima atau model regresi ini menunjukkan tingkatan yang baik (good overall model fit) sehingga model regresi dapat digunakan mengukur pengaruh konservatisme akuntansi terhadap underpricing saham IPO dalam kondisi asimetri informasi rendah. 


\section{Uji Signifikan Parameter Individual (Uji t)}

Hipotesis pertama pada regresi pertama merupakan model regresi yang digunakan untuk mengestimasi pengaruh konservatisme akuntansi yang tinggi akan menekan tingkat underpricing. Berdasarkan tabel 11 diketahui bahwa probabilitas CONS bernilai 0.8293 dan besar koefisien adalah 48.51257 dengan t hitung 0.216196 , dan signifikan pada $\alpha 0.05$. Hal ini berarti CONS tidak berpengaruh terhadap underpricing saham IPO dan tidak signifikan karena $t$ hitung $<\mathrm{t}$ tabel yaitu $0.216196<1.66071$. Dengan demikian hipotesis pertama (H1) tidak dapat diterima.

Hipotesis kedua pada regresi kedua merupakan model regresi yang digunakan untuk mengestimasi pengaruh konservatisme akuntansi terhadap tingkat underpricing jika asimetri informasi tinggi. Berdasarkan tabel 12 diketahui bahwa probabilitas CONS bernilai 0.4055 dan besar koefisien adalah 195.3602 dengan t hitung 0.840548, dan signifikan pada $\alpha 0.05$. Hal ini berarti CONS tidak berpengaruh terhadap underpricing saham IPO jika asimetri informasi tinggi dan tidak signifikan karena t hitung < t tabel yaitu $0.840548<1.67943$.

Hipotesis kedua pada regresi ketiga merupakan model regresi yang digunakan untuk mengestimasi pengaruh konservatisme akuntansi terhadap tingkat underpricing jika asimetri informasi rendah. Berdasarkan tabel 13 diketahui bahwa probabilitas CONS bernilai 0.1430 dan besar koefisien adalah 138936.3 dengan t hitung 1.567326, dan signifikan pada $\alpha 0.05$. Hal ini berarti CONS tidak berpengaruh terhadap underpricing saham IPO jika asimetri informasi rendah dan tidak signifikan karena $t$ hitung < t tabel yaitu $1.567326<1.74588$. Dari hasil regresi dalam penelitian ini, baik asimetri tinggi atau asimetri rendah, tidak terdapat pengaruh konservatisme terhadap underpricing. Dengan demikian hipotesis kedua (H2) tidak dapat diterima.

\section{PEMBAHASAN}

Pengaruh semakin tinggi konservatime akuntansi dalam pelaporan keuangan maka semakin rendah tingkat underpricing saham saat IPO

Hipotesis pertama pada penelitian ini adalah konservatisme akuntansi berpengaruh negatif terhadap underpricing saham saat IPO, dimana semakin konservatif laporan keuangan setahun sebelum IPO, semakin rendah tingkat underpricing pada saat IPO. Berdasarkan hasil penelitian, diketahui CONS berpengaruh dengan nilai koefisien positif yaitu 48.51257 dan tidak signifikan pada a 5\%. Hal tersebut menunjukkan bahwa tingginya penggunaan prinsip konservatisme akuntansi tidak dapat berpengaruh terhadap tingkat underpricing saham saat IPO. Temuan ini tidak mendukung hipotesis pertama.

Hasil penelitian ini tidak sesuai dengan pendapat Boulton et al (2011) yang mengungkapkan bahwa terdapat hubungan negatif antara tingkat underpricing dengan kualitas informasi laba. Konservatisme akuntansi membuat manajemen lebih sulit untuk melakukan overstating dari laba, dan membuat laporan keuangan tersebut lebih dapat diandalkan (Bushman dan Piotroski, 2006). Hasil penelitian ini juga tidak sesuai dengan argument Lin dan Tian (2012) yang menyatakan bahwa konservatisme akuntansi secara negatif berpengaruh terhadap underpricing saham IPO. Penerapan konservatisme akuntansi tidak menjadi patokan dalam menetukan harga pada saat IPO.

Hal ini disebabkan karena sesuai dengan teori keagenan bahwa manajer memiliki kesempatan untuk memaksimalkan kesejahteraannya sendiri dengan mengorbankan kepentingan pihak-pihak lain sehingga dengan ada atau tidaknya prinsip konservatisme akuntansi dalam laporan keuangan tidak akan dapat membantu menekan perilaku oportunis manajemen dalam 
memanipulasi laporan keuangan. Beberapa faktor yang menyebabkan hipotesis ini ditolak yang pertama karena tahun pengamatan hanya pada laporan keuangan satu tahun sebelum IPO dan tidak membandingkan dengan tahun-tahun sebelum IPO yang menyebabkan pengamatan menjadi sempit. Kedua, sampel yang digunakan hanya 97 perusahaan dari tahun 2015-2018 berbeda dengan penelitian sebelumnya memiliki sampel 674 dari tahun 2001-2009.

\section{Pengaruh asimetri informasi pada hubungan antara konservatisme akuntansi dan underpricing saham IPO}

Hipotesis kedua dalam penelitian ini mengenai dampak asimetri informasi sebelum IPO pada hubungan antara konservatisme akuntansi dan underpricing saham IPO. Seperti yang sudah dijelaskan pada bab sebelumnya, sampel dalam penelitian akan dibagi menjadi dua kelompok yaitu sampel dengan asimetri informasi tinggi dan sampel dengan asimetri rendah berdasarkan dua proksi yaitu umur perusahaan dan ukuran perusahaan. Dalam regresi pada tabel 12, koefisien pada CONS adalah sebesar 195.3602 untuk sampel dengan asimetri tinggi yang lebih rendah daripada koefisien CONS dengan asimetri rendah sebesar 138936.3 (Tabel regresi 3).

Hal ini membuktikan bahwa hubungan konservatisme akuntansi dan underpricing saham IPO akan lebih jelas untuk perusahaan yang mempunyai asimetri informasi rendah daripada asimetri tinggi. Ukuran perusahaan besar atau kecil tidak menjadi pertimbangan bagi investor untuk membeli saham pada saat IPO, bagi investor yang terpenting adalah perusahaan tersebut dapat memberikan return yang memuaskan. Umur perusahaan tidak dapat menggambarkan tinggi atau rendahnya asimetri informasi dari laporan keuangan, dimana faktanya perusahaan yang lebih matang atau lama ternyata belum tentu memberikan informasi laporan keuangan yang akurat. Hal tersebut dapat terjadi dikarenakan adanya perbedaan sampel dan periode penelitian. Dengan demikian temuan ini tidak mendukung hipotesis kedua.

Hasil penelitian ini tidak sesuai dengan penelitian yang dilakukan oleh Lin dan Tian (2012) yang menghasilkan kesimpulan bahwa asimetri informasi yang tinggi akan lebih menonjolkan pengaruh negatif antara konservatisme akuntansi dengan underpricing saham IPO. Hasil penelitian ini juga tidak mendukung pendapat dari Stoll dan Curley (1970) yang menyatakan bahwa perusahaan yang lebih muda kecenderungan memiliki asimetri informasi yang lebih besar. Umur perusahaan yang lebih tua membuat informasi lebih tersebar kepada masyarakat. Hal tersebut membuat gap informasi dapat dikurangi dengan melakukan proses screening dan signaling oleh masyarakat khusunya calon investor. Harga yang tercermin dalam penawaran umum juga dapat diandalkan dan berimplikasi pada tingkat underpricing saham yang menjadi rendah.

\section{SIMPULAN, KETERBATASAN DAN SARAN Kesimpulan}

Berdasarkan hasil temuan penelitian dan pengujian hipotesis yang telah dilaksanakan, hasil penelitian didapatkan bahwa konservatisme akuntansi tidak memiliki pengaruh terhadap tingkat underpricing saham saat IPO yang diukur dengan melihat total akrual pelaporan sebelum IPO. Temuan dalam penelitian ini tidak mendukung teori bahwa penerapan prinsip konservatisme akuntansi membuat manajemen lebih sulit untuk melakukan overstating dari laba, dan membuat laporan keuangan tersebut lebih dapat diandalkan.

Dampak konservatisme akuntansi terhadap underpricing saham IPO tidak berpengaruh untuk perusahaan dengan asimetri informasi tinggi maupun perusahaan dengan asimetri 
informasi rendah. Temuan ini tidak mendukung bahwa asimetri informasi yang lebih tinggi menciptakan lebih banyak insentif untuk akuntansi konservatif pada perusahaan yang IPO.

\section{Keterbatasan}

Penelitian telah berusaha merancang dan mengembangkan penelitian sedemikian rupa, namun masih terdapat beberapa keterbatasan dalam penelitian ini yang masih perlu diperbaiki bagi peneliti selanjutnya, antara lain asimetri informasi perusahaan hanya diukur dari umur perusahaan hingga tercatat di Bursa Efek Indonesia dan ukuran perusahaan hanya dilihat dari tota aset saja. Konservatisme akuntansi hanya diukur menggunakan total akrual saja. Tingkat tinggi atau rendahnya underpricing hanya diukur dengan Market Adjusted Abnormal Return saja.

\section{Saran}

Dari keterbatasan-keterbatasan dalam penelitian ini, peneliti menghimbau untuk dilakukan pengembangan dan peningkatan kualitas untuk penelitian selanjutnya, disarankan untuk melakukan beberapa hal sebagai berikut untuk memperluas proksi yang digunakan dalam penelitian dalam pengukuran asimetri informasi seperti melihat pertumbuhan penjualan dan good corporate governance. Untuk memperluas proksi yang digunakan dalam menilai tingkat konservatisme akuntansi. Untuk menambahkan serta memperluas proksi dalam mengukur tingkat underpricing seperti memakai metode Difference Market To Book Ratio.

\section{DAFTAR PUSTAKA}

Akerlof GA. (1970). The Market for "Lemons": Quality Uncertainty and the Market Mechanism. The Quarterly Journal of Economics, 84(3), 488-500.

Alexander, H. 2007. Analisis Faktor-Faktor yang Mempengaruhi Underpricing Saham Pada Perusahaan Go Public Di Bursa Efek Jakarta. Skripsi. Jurusan Akuntansi pada Fakultas Ekonomi: Universitas Sanata Dharma.

Amihud, Y., \& Mendelson, H. (1986). Asset pricing and the bid-ask spread. Journal of Financial Economics, 17(2), 223-249.

Anggarwal, R, Leal, R, \& Hernandez, L. (1993). The aftermarket perfomance of initial public offering in Latin Amerika. Financial Management, 22(1), 42-53.

Ball, R., \& Shivakumar, L. (2008). Earnings quality at initial public offerings. Journal of Accounting and Economics, 45(2-3), 324-349.

Baron. DP. (1982). A Model of the Demand for Investment Banking Advising and Distribution Services for New Issues. The Journal of Finance, 37(4), 955-976.

Basu, S. (1997). The conservatism principle and the asymetric timeliness of earnings. Journal of Accounting and Economics, 24(1), 3-37.

Beatty, R. P. (1989). Auditor reputation and the pricing of initial public offering. The Accounting Revie, 64(4), 693-709.

Beaver, W. H., Ryan, S.G. (2000). Biases and lags in book value and their effects on the ability of the book-tomarket ratio to predict book return on equity. Journal of Accounting Research, 38, 127-148.

Bliss, J. H. (1924). Management through accounts. New York, NY: The Ronald Press Co.

Boulton, T. J., Smart, S. B., \& Zutter, C. J. (2011). Earnings quality and international IPO underpricing. The Accounting Review, 86(2), 483-505. 
Burkart, M., Gromb, D., \& Panunzi, F. (1997). Large shareholders, monitoring, and the value of the firm. Quarterly Journal of Economics, 122(3), 693-728.

Bushman, R., \& Piotriski, J. (2006). Financial reporting incentives for conservative accounting; The influence of legal and political institutions. Journal of Accounting and Economics, 42(1-2), 107-148.

Cai, J. L. Y., \& Qian, Y. (2007). Information asymmetry and corporate governance. Working Paper. Drexel University's LeBow College of Business.

Chishty, M., Hasan, I., \& Smith, S. (1996). A note on underwriter competition and initial public offerings. Journal of Business Finance \& Accounting. 23(5), 905-913.

Dierkens N. (1991). Information Asymmetry and Equity Issues. The Journal of Financial and Quantitative Analysis. 26(2), 1-48.

Eisenhardt, K. M. (1989). Agency theory: An Assesment and Review. The Academy of Management Review, 14(1), 57-74.

Francis, J., \& Martin, X. (2010). Acquisition profitability and timely loss recognition. Journal of Accounting and Economics, 49(1-2), 161-178.

García Lara, J., García Osma, B., \& Penalva, F. (2009). Accounting conservatism and corporate governance. Review of Accounting Studies, 14(1), 161-201.

Ghozali, Imam. (2016). Aplikasi Analisis Multivariate dengan Program IBM SPSS 23. Semarang: Badan Penerbit Universitas Diponegoro.

Givoly, D., \& Hayn, C. (2000). The changing time-series properties of earnings, cash flows and accruals: Has financial reporting become more conservative?. Journal of Accounting and Economics, 29(3), 287-320.

Godfrey, J., Hodgson, A., Tarca, A., Hamilton. J., \& Holmes, S. (2010). Accounting Theory, 7th Edition. Milton QLD: John Wiley \& Sons Australia.

Hanafi, M. (2004). Manajemen Keuangan. Yogyakarta: BPFE.

Haniati, S. \& Fitriany. (2010). Pengaruh konservatisme akuntansi terhadap asimetri informasi dengan menggunakan beberapa model pengukuran konservatisme, Simposium National Akuntansi 3 Purwokerto.

Haw, I. M., Lee, J. J., \& Lee, W. J. (2010). Debt financing and accounting conservatism in private firms. Working paper series. Available at SSRN eLibrary.

Herawati, H., Achsani, N, A., \& Hartoyo, S. (2016). Model penetapan harga IPO berdasarkan valuation. Jurnal Ilmiah Manajemen, 6(3), 434-448.

Hoque, H. (2014). Role of asymmetric information and moral hazard on IPO underpricing and lockup. Journal of International Financial Market, Institusions \& Money, 30, 81-105.

Ikatan Akuntan Indonesia (IAI). (2002). Kerangka Konseptual. Jakarta: IAI.

Jensen, M., \& Meckling, W. (1976). Theory of the firm: managerial behavior, agency cost and ownership structure. Journal of Financial Economics, 3, 305-360.

Jogiyanto. (2010). Teori Portofolio dan Analisis Investasi. Yogyakarta: BPFE UGM.

Kaplan, R. S., \& Atkinson, A. A. (1998). Advanced management accounting. Upper Saddle River, N.J: Prentice Hall.

Khan, M. \& Whatts, R. L. (2009). Estimation and validation of a firm-year measure of conservatism. Journal of Accounting and Economics, 84(2/3), 132-150.

Kim, B. H., \& Pevzner, M. (2010). Conditional accounting conservatism and future negative surprises: An empirical investigation. Journal of Accounting and Public Policy, 29(4), 311-329. 
Kisoe, Donald E., Jerry J Weygandt., \& Terry D Warfield., (2009). Intermediate Accounting. 13th edition. Wiley International Edition.

Lafond, Watts, R.L. (2008). The Information Role Of Conservative Financial Statements. http://papers.ssrn.com.

Leland HE, Pyle DH. (1977). Informational Asymmetries, Financial Structure, and Financial Intermediation. The Journal of Finance, 32.(2), 371-387.

Li, Y. (2009). Empirical researc on IPO underpricing of A-share companies in China after the implementation of book building mechanism. Economist, 12, 84-86.

Lin, Z., \& Tian, Z. (2012). Accounting conservatism and IPO underpricing: China evidence. Journal of International Accounting, Auditing and Taxation, 21, 127-144.

Ljungqvist, A. (2007). IPO underpricing pada B. Espen Fckbo. Handbook of Corporate Finance. Empirical Corporate Finance. Amsterdam: Elsevier BV, 1

Loughran, T., \& Ritter, J. (2004). Why has IPO underpricing changed over time?. Financial Management, 33(3), 5-37.

Mueller, H., \& Inderst, R. (2001). Ownership concentration, monitoring, and the agency cost of debt. Working Paper Series. Available at SSRN eLibrary.

Myers SC, Majluf N S. (1984). Corporate Financing And Investment Decisions When Firms Have Information That Investors Do Not Have. Journal of Financial Economics, 13, 187221.

Rahmawan, M., S. 2015. Analisis Pengaruh Informasi Asimetri dan Konservatisme Akuntansi Terhadap Tingkat Underpricing Saham Saat IPO. Skripsi Jurusan Akuntansi pada Fakultas Ekonomi Universitas Indonesia: Depok.

Ritter JR.. (1987). The Costs Of Going Public. Journal of Financial Economics, 19, $260-781$.

Ritter, Jay R., \& Ivo Welch. (1999). A review of IPO activity, pricing, and allocations. Journal of Finance, 57, 1795-1828.

Riyanto E. 2013. Evaluasi Harga Wajar Saham PT Waskita Karya Pada Saat Penawaran Umum Perdana Tahun 2012. Tesis. Fakultas Ekonomika dan Bisnis Universitas Gadjah Mada: Yogyakarta.

Rock, K. (1986). Why new issues are underpriced. Journal of Financial, 15(1-2), 187-212.

Sari, C, \& Desi, A. (2009). Konservatisme akuntansi dan faktor-faktor yang mempengaruhinya. Simposium Nasional Akuntansi X11. Palembang.

Schroeder, Richard G., Myrtle, W. Clark \& Jack M. Cathey. (2001). Financial Accounting Theory and Analysis. 7th edition. New York: John Wiley and Sons Inc.

Scott, William R. (2000). Financial Accounting Theory. 2nd edition. Toronto, Ont: Prentice Hall Canada Inc.

Spence M. (2002). Signaling in Retrospect and the Informational Structure of Markets. The American Economic Review, 92(3), 434-459.

Spence, A. M. (1973). Job Market Signalling. Quarterly Journal of Economics, 87(3) 355-374.

Sterling, R. R. (1970). Theory of The Measurement of Enterprise Income University of Kansas Press. Lawrence, Kansas.

Stoll, H. R., \& Curley, A. J. (1970). Small Business and The New Issues Market For Equities. The Journal of Financial and Quantitative Analysis, 5(3), 309-322.

Su, D., \& Fleisher, B. M. (1999). An empirical investigation of underpricing in Chinese IPOs. Pacific-Basin Finance Journal, 7(2), 173-202.

Suaryana, A. (2008). Pengaruh Konservatisme Laba Terhadap Koefisien Respons Laba, Jurnal Ilmiah Akuntansi dan Bisnis, 3(1). 
Suharyadi \& Purwanto. (2009). Statistika untuk Ekonomi dan Keuangan Modern. Jakarta: Salemba Empat.

Sutedi, A. (2010). Hukum Perizinan Dalam Sektor Pelayanan Publik, Jakarta: Sinar Grafika.

Suwardjono. (2014). Teori Akuntansi: Perekayasaan Pelaporan Keuangan. BPFE Yogyakarta: Yogyakarta.

Tandelilin, E. (2010). Portofolio dan Investasi: Teori dan Aplikasi. Yogyakarta: Kanisius.

Watts, R. L. (2003). Conservatism in Accounting, Part II: Evidence and Research Opportunities. Accounting Horizons, 17(4), 287-301.

Welch I, Ritter J. (2002). A Review Of Ipo Activity, Pricing, And Allocations Working Paper 8805 National Bureau Of Economic Research 1050 Massachusetts Avenue Cambridge. 144.

Wolk H, Tearney MG, Dodd JL. (2001). Accounting Theory: A Conceptual and Institutional Approach. South-Western College Publishing.

Wolk, H., M. Tearney, dan J. Dodd. (2000). Accounting Theory: A Conceptual and Institusional Approach. 3th edition. South Western Collange Publishing. 